\title{
Protein E6, Human Papillomavirus Type
} 16

National Cancer Institute

\section{Source}

National Cancer Institute. Protein E6, Human Papillomavirus Type 16. NCI Thesaurus.

Code C1397.

Protein E6 (158 aa, $19 \mathrm{kDa}$ ) is encoded by the human papillomavirus type $16 \mathrm{E} 6$ gene.

This protein is involved in both transcriptional activation and deg radation of cellular tumor antigen $\mathrm{p53.}$ 